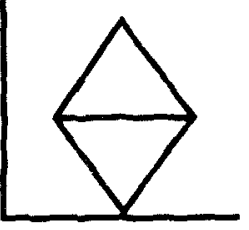

\title{
Setting Standards in Petrology: The Commission on Systematics in Petrology
}

\section{by Peter A. Sabine}

The IUGS Commission on Systematies in Petrology coordinates international efforts in the field of petrological nomenclature. To reconcile contrasting interpretations of what individual names mean in different languages in different countries is necessarily a complex and slow process. Nevertheless, one of the finest achievements of IUGS in setting international standards has been the now widely accepted modal classification of plutonic and volcanic rocks developed by the Commission. (Ed.) Igneous Rocks

Work on the classification and nomenclature of igneous rocks began with an enquiry by Albert Streckeisen from Switzerland (1967). As a result T.F.W. Barth (Norway), then President of IUGS, encouraged the formation of a Commission of Petrology (see Table $l$ for a list of Commission officers). A Subcommission on the Systematics of Igneous Rocks with Streckeisen as Chairman was soon established to discuss the systematics, classification and nomenclature of igneous rocks and to present definite proposals to IUGS. A long discussion (Streckeisen, 1973, 1976; Sabine, 1974; Sørensen, 1981) among geologists in over 25 countries, resulted in the acceptance for the phanerocrystalline rocks of the double triangle QAPF (Quartz, Alkali-feldspar, Plagioclase, Feldspathojd, Fig. 1), as the basis of a widely agreed classification based on modal mineralogy.

Aside from establishing the main classification of plutonic and voleanic rocks in the QAPF double triangle, there have been other decisions, for example on ultramafic rocks, the distinction between diorite and gabbro, use of colour index, as well as on pyroclastic, charnockitic, and other rocks

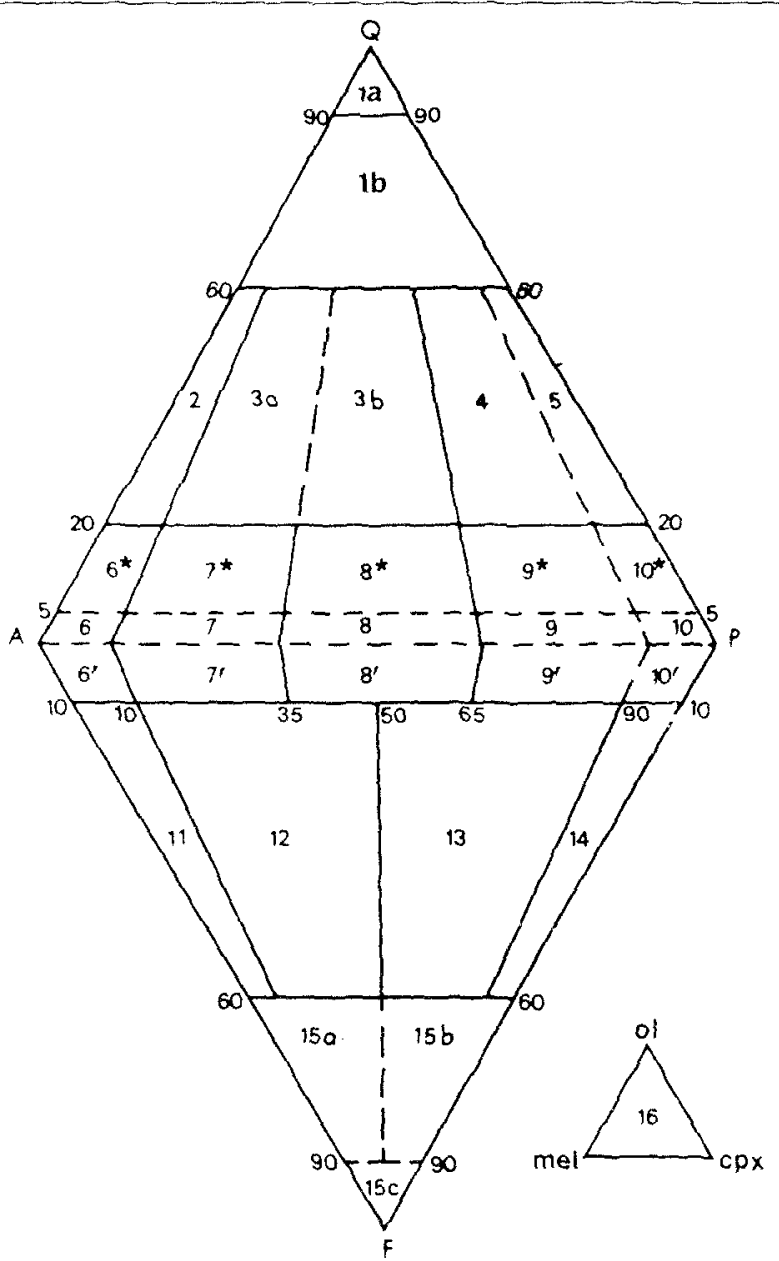

\begin{abstract}
Plutonic rocks. - la - Quartzolite (silexite), (>900); Ib - quartz-rich granitoids (60-900); 2 - Alkali-feldspar granite; 3 - Granite; 4 - Granodiorite; 5 - Tonalite; $6^{*}$ - Alkali-feldspar quartz syenite; $7^{*}$ - Quartz syenite; $8^{*}$ - Quartz monzonite; $9^{*}$ - Quartz monzodiorite/ Quartz monzogabbro; $10^{*}$ - Quartz dioritel Quartz gabbro/Quartz anorthosite; 6 - Alkali-feldspar syenite; 7 - Syenite; 8 - Monzonite:

9 - Monzodiorite/Monzo-gabbro; 10 - Diorite Gabbro/Anorthosite; 6' - Foid-bearing alkalifeldspar syenite; $7^{\prime}$ - Foid-bearing syenite; $8^{\prime}$ - Foid-bearing monzonite; 9' - Foid-bearing monzodiorite/monzo-gabbro; 10' - Foid-bearing dioritelgabbro; 11 - Foid syenite; 12 - Foid monzosyenite (syn. Foid plagisyenite); 13 - Foid monzodiorite/Foid monzogabbro (both syn. Essexite); 14 - Foid diorite/Foid gabbro (syn. Theralite); 15 - Foidolites; 16 - Ultramafic rocks lol-olivine, cpx-clinopyroxene, mel-melilite).
\end{abstract}

Volcanic rocks. - 2 - Alkali-feldspar rhyolite; 3-Rhuolite; 4 \& 5 - Dacite; 6* - Quartz-alkalifeldspar trachyte; $7^{*}$ - Quartz trachyte; $8^{*}-$ Quartz latite; 6 - Alkali-felaspar trachyte; 7 - Trachyte; 8 - Latite; 6' - Foid-bearing alkali-feldspar trachyte; $7^{\prime}$ - Foid-bearing Trachyte; $8^{\prime}$ - Foidbearing latite; 9 \& 10 - Andesite and Basalt; 11 - Phonolite; 12 - Tephritic phonolite; 23 - Phonolitic tephrite; 14 - Tephrite, basanite: $15 \mathrm{z}$ - Phonolitic foidite; $15 \mathrm{~b}$ - Tephritic

(basanitic) foidite; $15 \mathrm{C}$ - Foidite; 16 - Ultramafic extrusive rocks.

Figure 1. QAPF diagram for plutonic and modally-determinable volcanic rocks. Q - Quartz. A - Alkali feldspars (orthoclase, microcline, perthite, anorthoclase, albite Anoo-05). P - Plagioclase Ano5-100, scapolite. $F$ - Feldspathoids ('foids'). $Q+A+P=100$ or $F+A+P=100$. Classification and nomenclature where possible according to modal mineral content (measured in volume percentage). 
(Streckeisen, 1974, 1978, 1979, 1980; Le Bas and Sabine, 1980; Schmid, 1981; Sørensen, 1986).

As shown in Figure 1 the classification of voleanic rocks is also based on modal mineral contents and is consistent with that of the plutonic rocks (Streckeisen, 1978, 1979, 1980; Sabine, 1978). However, when the modal contents of volcanic rocks cannot be determined, recourse must be made to a chemical classification (Fig. 2), plotted as Total Alkali against Silica (TAS). Decision to use this simple system was influenced by the difficulties found in using systems involving CIPW norms, arising from assignment of normative albite to alkali-feldspar or plagioclase.

In the development of the TAS diagram as many as possible of the common rock names were retained, using chemical analyses selected from the CLAIR and PETROS data bases (Le Maitre, 1982); some 24,000 names were plotted to arrive at the classification (Le Bas et al., 1986). The TAS diagram is for use with fresh rocks (Le Bas et al., 1986; Le Maitre, 1984; Zanettin, 1984), but studies on a wide variety of altered British volcanic rocks (Sabine et al., 1985) have shown that many of these can also be satisfactorily classified by TAS.

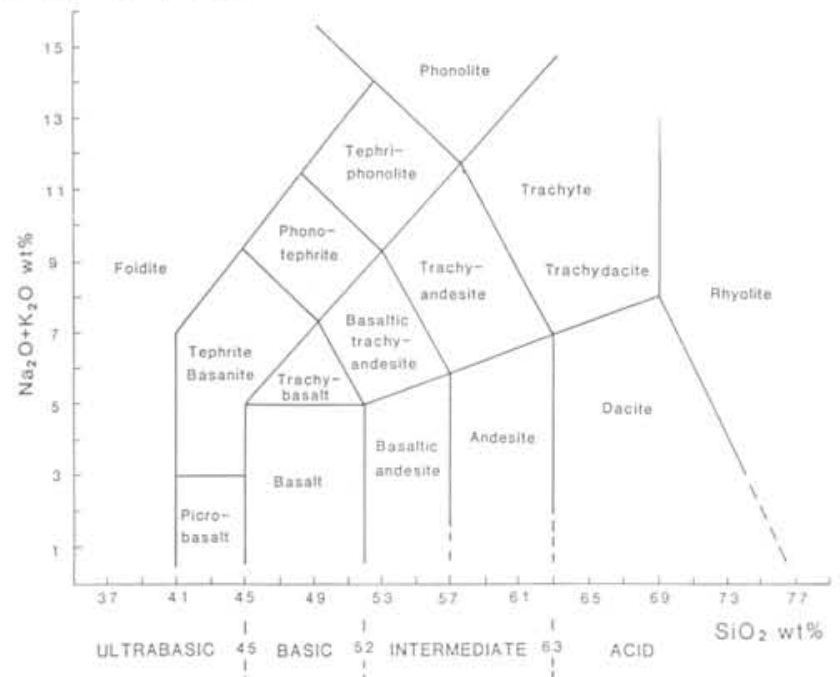

Figure 2. The total alkali-silica (TAS) diagram for use with volcanic rocks when modal data are not available.

At the latest meeting of the Subcommission in Copenhagen (Fig. 3), decisions on the TAS divisions were finally agreed as shown in Figure 2, with coordinates as given in Le Bas and others (1986). Various problems remain in the interpretation of different names, including their usage in different languages. After extensive discussion, the IUGS system has been largely reconciled with Russian usage, and the classifications recommended by the Subcommission are now widely used in the U.S.S.R. (Efremova, 1988) and in other language regions (Le Bas et al., 1988; Teruggi, 1980). For example, earlier difficulties in the use of the term "subalkaline basalt" were fully discussed in the Copenhagen meeting, and the term is now taken to mean a basalt with normative hypersthene and quartz. However, the classification of the nepheline- and leucite-bearing rocks, especially melanephelinites and other potassic rocks, poses problems that still need to be resolved (Le Bas, 1989).

The carbonatites, which are igneous rocks with $>508$ earbonate minerals, pose unusual problems of nomenclature, compounded by the difficulties of determining the rockforming carbonate species present. These may include ferroan dolomite, ankerite, breunnerite and magnesite, and some may be intimately intergrown. A modification by A.R. Woolley (U.K.) of the scheme proposed earlier (Streckeisen,
$1974,1978,1979,1980)$, in which the principal minera! species and other characteristic species are used a s prefixes, has been accepted with minor modifications.

Following ratification of the nomenclature at the Paris Congress in 1980, a "pyroclast" is taken to have beer generated by disruption as a direct result of volcanic action. Pyroclastic deposits, in a broad sense, are subject to a granulometric classification (Schmid, 1981; Le Bas anc Sabine, 1980).

A major recent task for the Subcommission has been the preparation of a book entitled A Classification of Igneous Rocks and Glossary of Terms: Recommendations of the International Union of Geological Sciences Subcommission on the Systematics of Igneous Rocks (Le Maitre et al., 1989). Definitions are given for all igneous rocks, which are classified so as to emphasize those that are recommendec by the Subcommission, and the book is accompanied by $\varepsilon$ large flow chart for classifying rocks.

\section{Data Bases in Petrology}

One of the more important developments in petrology in recent years has been the application of electronic databases. A world database for igneous petrology, IGBADAT, which originated during IGCP Project 163 and which has close relationships with Project 239, has been established under the Subcommission on Data Bases for Petrology (Chayes, 1985), set up at the Moscow Congress and now well into its work. In excess of 12,400 specimen deseriptions are now contained in this database, which is distributed by World Data Centre A. Vastly greater amounts of information are now available for delineation of rock types and their average chemical compositions than were available only a few years ago. Indeed, the holdings have themselves doubled in the last decade.

\section{Metamorphic Rocks}

Also set up at the Moscow Congress was the Subcommission on the Systematies of Metamorphic Rocks. Members from 21 countries collaborate, and nine Study Groups have been established to deal with very low grade metamorphics, high pressure rocks, granulites, contact-metamorphic rocks, deformed rocks and structures, migmatites, carbonatic and metasomatic rocks, and impactites. Some 200 other scientists are participating in this work via questionnaires sent out by the Subcommission and Study Groups.

The metamorphic rocks are defined as far as possible by modal composition and/or structure, but unfortunately no single classificatory system is available or acceptable world-wide. The number of common rock terms for metamorphic rocks is very small and the variation in composition very large. The Subcommission has accordingly sought to define common rock terms such as gneiss, schist, amphibolite, in as broad a sense as possible in order to cover the whole variation and to avoid ambiguities. It accepts that overlaps will occur, but it hopes to establish definitions that are most widely applicable to each specific rock term, and acceptable to the majority of earth scientists.

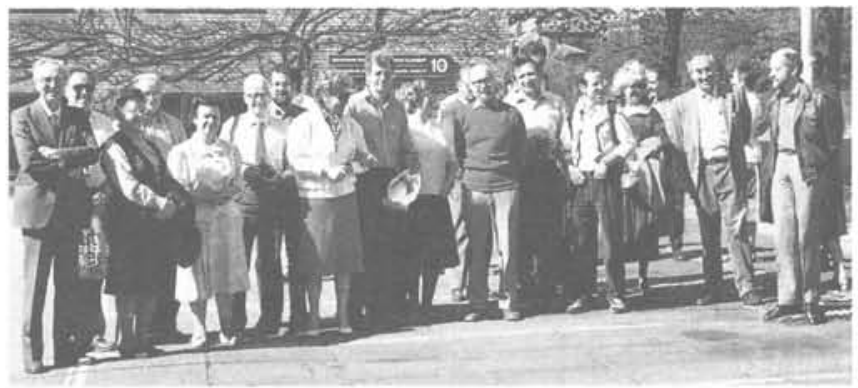

Figure 3. Participants in the 1988 Copenhagen meeting of the IUGS Subcommission on systematics of Igneous Rocks, in front of the Geological Institute. 
TABLE 1: Principal Officers of the

Commission on Systematics in Petrology

Commission on Petrology (Created 1961)

became Commission on Systematics in Petrology (1972);

President: C.W. Correns (F.R.G.) A. Streckeisen (Switzerland) $(1967-68)$ $(1968-80)$

B. Zanettin (Italy)

P.A. Sabine (U.K.)

$(1980-84)$

(1984 - )

Subcommission on Igneous Rocks (Created 1968)

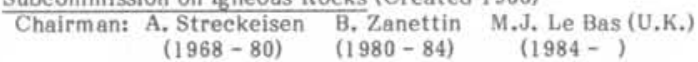

Subcommision on Metamorphic Rocks (Created 1984)

Chairman: R. Schmid (Switzerland) $(1984-)$

Subcommision on Data Bases in Petrology (Created 1984) Chairman: F. Chayes (U.S.A.)

$(1984-)$

Provisional agreement has been reached on approximately 55 terms, and most metamorphic rock terms are expected to be defined by the end of 1989. A glossary of common, as well as special and uncommon, metamorphic rock terms, together with structural and genetic terms, has been proposed. It has not yet been decided whether or not the problem of metamorphic facies should be tackled by the Subcommission.

\section{Future Strategy}

Although most igneous rock names were defined during the last decade of the nineteenth, and the earlier part of the present century, numerous new names continue to be published. Although many deal with rocks of very unusual mineralogy, important types continue to be established, such as komatiite and meimechite. The huge area of suboceanic volcanic rocks now being explored is also raising problems of classification and distinction of different types. It will be a measure of the success of the Subcommission on Igneous Rocks if it can bring more order to this field and find universal acceptance.
The first important decisions are beginning to come from the work of the Metamorphic Subcommission, which hopes also to produce a glossary in due course. In recent years the rapid advances in instrumental analytical techniques and the voluminous results that have been produced are complemented by the establishment of petrological data bases that fall within the purview of the Subcommission on Data Bases in Petrology. This is undoubtedly a field that will assume increasing importance.

Discussions have also taken place concerning the establishment during the Washington Congress of a Subcommission on Systematics of Sedimentary Rocks. The topic has assumed increasing importance in recent years, especially in the field of petroleum geology, and the formation of such a group would complete the range of work for the Commission on Systematics in Petrology.

\section{Acknowledgements}

I thank G. Bellieni, F. Chayes, M.J. Le Bas, R. Schmid, A.R. Woolley and B. Zanettin for helpful comments. I also thank them and the many other geologists, especially A. Streckeisen, who have contributed so much to the work of the Commission.

Dr. Peter A. Sabine (19 Beaufort Road, Hanger Hill, Ealing, London W5 3EB, U.K.) is retired Chief Scientific Officer and Deputy Director of the Institute of Geological Sciences. A former Secretary and Vice-President of the Geological Society of London, he worked on many British rocks including alkaline and contactmetamorphic types and granites. $\mathrm{He}$ is now Chairman of the Commission on Systematics in Petrology.

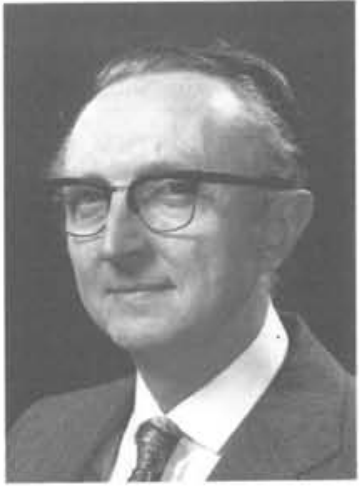

References

Chayes, F., 1985. IGBADAT: a world data base for igneous petrology. Episodes, v. 8, no. 4 , p. $245-251$.

Efremova, S.Y, 1988. The meeting of the Terminological Commission of the DepartErtemal Petrographical Committec. Sovetskaya fieologiys, no, 2, D, 124-125. (In Russian).

Le Bas, M.J., 1989, (in press). Nephelinitic and basanitic rocks. Journal of Petrology.

Le Bas, M.J., Le Maitre, R.W., Streckeisen, A. and Zanettin, B., 1986. A chemical classifieation of voleanic rocks tased on the Total Alkali-Silica diagram. Journal of Petrology, v. 27 , part 3, p. 745-750.

Le Bas, M.J., Le Maitre, R.W., Streckeisen, A. and Zanettin, B., 1988. A chemical elassification of voleanic rocks based on the Total Alkali-Silica diagram. Dizhi keji Dongtai, v. 9, p. 25-29. (In Chinese).

Le Bas, M.J, and Sabine, P.A., 1980. Progress in 1979 on the nomenciature of pyrochastic materials, Geologieal Magazine, v, 117, no. 4, p. 389-391.

Le Maitre, R.W., 1982. Numerical Petrology: statistical interpretation of geochemical data. Elsevier, Amsterdam, $281 \mathrm{p}$.

Le Maitre, R.W., 1984. A proposal by the IUGS Subeommission on the Systematics of Igneous Rocks for a chemical classification of volcanic rocks based on the total all

Le Maitre, R.W., Bateman, P., Dudek, A., Keller, J., Lameyre, P., Le Bas, M.J., Sabine, P.A., Schmid, R., Sørensen, H., Streckeisen, A., Woolley, A.R., and Zanettin, B., 1989. A classification of igneous roeks and glossary of terms. Recommendations of the IUGS Subcommission on the Systematics of igneous Rocks, Blackwell, London, 204p.

Sabine, P.A., 1974. How should rocks be named? Geological Magazine, v. 111, no. 2, p. $165-176$.

Sabine, P.A., 1978. Progress on the nomenclature of volcanic rocks carbonatites, melilite-rocks and tamprophyres. Geological Magazine, v. 115 , no. 6, p. 463-466.

Sabine, P.A. Harrison, R.K. and Lawson, R.1. 1985. Classification of voleanic rocks of the British isles on the total alkall oxide-silica diagram, and the significance of alteration. Report of the British Geological Survey, v. 17, no. 4, p. 1-9.

Schmid, R., 1981. Descriptive nomenclature and classification of pyroclastic deposits and fragments: Recommendations of the IUGS Subcommission on the Systematies of Igoeous Rocks. Geology, v. 9, no. 1, p. 41-43; Neves Jahrbuel für Mineralogie, Monatshefte, v. 4, p. 190-196; Geologische Rundschau, v. 70, no. 2, p. 794-799.

Sórensen H. 1981, Hxad skal bjergarterne hedde? Dansk geologisk Forenings, Arsskrift for 1980 , p. $39-46$.
Sórensen, H., 1986. Hvad skal bjergarterne hedde? II. Vulkanske bjergarter, pyroclastet m.v. Dansk geologisk Forening, Arsskrift for 1985, p. 59-65.

Streckeisen, A., 1967. Classification and nomenelature of igneous rocks (Final report of an Inquiry). Neues Jahrbuch für Mineralogie. Abhandlungen, y. 107, Heft 2, p. 144-214, and in 107 , Heft 3, p, 215-240.

Streekeisen, A, 1973. Plutonic rocks Classification and nomenclature recommended by the IUGS Subcommission on the Systematics of Igneous Rocks. Geotimes, v. 18, no. 10, p. 26-30.

Streckeisen, A., 1974. How should charnockitic rocks be named? In: Belliere, J. and Puchesne, A.' (eds). Ǵêlogie des domaines cristallins Société Géologique de Belgique, Liège, p. $349-360$.

Streckeisen, A., 1976. To each plutonic rock its proper name. Earth-Seience Reviews, v. 12, no. 1, p. 1-33.

Streckeisen, A., 1978. Classiffeation and nomenelature of voleanic rocks, lamprophyres, Streckeisen, A., 1978. Classiffeation and nomenclature of a suggestions of the IUGS carbonatites, and metiltic rockst kecommendations and subgestions fir Yineralogie. Abhandlungen, $y, 134, \mathrm{p}, 1-14$.

Streckeisen, A., 1979. Classification and nomenclature of voleanic rocks, lamprophyres, carbonatites, and melilitic rocks; recommendations and suggestions of the IU GS Subcommission on the Systematies of Igneous Rocks. Geology, v. 7, 1979, p. 331-335

Streckeisen, A. (compiler), 1980. Classification and nomenclature of volcanic rocks, Streckeisen, A. (eompter, And melilitic rocks: $10 \mathrm{CS}$ Subcommission on the Systematics of taneous Alocks, reeommendations and suggestions, Geologische Rundschau, v, 69, no, of grneous $194-207$.

Teruggi, M.E., 1980. La elasificaçion de las rocas igneas (UUGS), con glossario ingliscastellano e castellano-inglis de los terminos usados. Coleccion ciençias de la Terra, No. ecal, Buenos Aires, Angentina 34p.

Zanettin, B., 1984. Proposed new chemical ciassification of voicanic rocks. Episodes, v. 7, no. 4, p. $19-20$. 